\title{
MENINGKATKAN HASIL BELAJAR MATEMATIKA SISWA PADA MATERI PERSEGI DAN PERSEGI PANJANG MELALUI PENERAPAN METODE DISCOVERY LEARNING DI KELAS III SD NEGERI 2 BARANGKA
}

\author{
Wa Ambo 1,a), Muhammad Yasin ${ }^{2}, \mathrm{La} \mathrm{Ili}^{2}$ \\ ${ }^{1}$ Alumni Jurusan Pendidikan Guru Sekolah Dasar, FKIP Universitas Halu Oleo, \\ J1. H.E.A. Mokodompit Kendari 93232, Indonesia \\ ${ }^{2}$ Dosen FKIP Universitas Halu Oleo, Jl. H.E.A. Mokodompit Kendari 93232, \\ Indonesia \\ a)e-mail:waambo4@gmail.com
}

\begin{abstract}
ABSTRAK
Penelitian ini bertujuan untuk meningkatkan hasil pelajaran matematika siswa pada materi persegi dan persegi panjang melalui penerapan metode discovery learning. Penelitian ini menerapkan desain penelitian tindakan kelas dengan subyek penelitian siswa kelas III SDN 2 Barangka. Teknik analisis data dalam penelitian ini adalah statistik deskriptif. Hasil obeservasi, evaluasi, dan refleksi pada setiap tindakan perbaikan pembelajaran menunjukan bahwa pada tindakan siklus pertama, ratarata yang dicapai siswa pada evaluasi hasil belajar adalah 71,00 atau 66,7\% dengan jumlah siswa 10 orang dari 15 yang diteliti. Pada evaluasi hasil belajar siklus II rata-rata 81,00 atau 86,7\% dengan jumlah siswa 13 orang dari 15 yang diteliti.
\end{abstract}

Kata kunci: Hasil Belajar, Metode Discovery Learning

\author{
IMPROVING STUDENT LEARNING OUTCOMES IN MATH MATERIALS SQUARE AND \\ RECTANGLE THROUGH APPLICATION OF DISCOVERYLEARNING \\ METHOD IN CLASS III SD STATE 2 BARANGKA
}

\begin{abstract}
This study aims to improve students' mathematics learning outcomes on the subject of square and rectangular material through the application of discovery learningmethod. This research applies classs action research design with research subject of third grader of SDN 2 Barangka. Data analysis technique in this research is descriptive statistic. The result of observation, evalution, and reflection on each learning improvement action show that in the first cycle action, the average achieved by students in evaluating learning outcomes is 71.00 or $66.7 \%$ with the number of students 10 out of the 15 studied. In the evaluation of learning outcomes of the second cycle an average of 81.00 or $86.7 \%$ with the number of students 13 people out of 15 studied.
\end{abstract}

Keyword: : Student Achieveme, Discovery Learning Method.

\section{PENDAHULUAN}

Pendidikan merupakan bagian integral dalam pembangunan. Proses pendidikan tak dapat dipisahkan dari proses pembangunan itu sendiri. Pembangunan diarahkan dan bertujuan untuk mengembangkan sumber daya yang berkualitas.Manusia yang berkualitas dapat dilihat dari segi pendidikan.Undang-undang Nomor 20 Tahun 2003 tentang sistem pendidikan nasional menyebutkan, bahwa pendidikan nasional berfungsi mengembangkan kemampuan membentuk watak serta peradaban bangsa yang bermartabat dalam rangka mencerdaskan kehidupan bangsa. 
Matematika merupakan salah satu ilmu pengetahuan yang dikembangkan dalam rangka menopang daya nalar siswa untuk dapat memahami kondisi yang ada disekitarnya, namun banyak kasus yang menunjukkan bahwa matematika merupakan mata pelajaran yang masih sulit dipahami oleh siswa yang mengakibatkan rendahnya prestasi belajar siswa.Oleh sebab itu perlu adanya upaya perbaikan pembelajaran matematika khususnya pada tingkat sekolah dasar (SD) yang merupakan awal dari penanaman konsepkonsep matematika.

Mempelajari matematika merupakan suatu bentuk belajar yang dilakukan dengan penuh kosentrasi dan terstruktur, yang pelaksanaannya dibutuhkan suatu proses aktif individu untuk memperoleh pengalaman dan pengetahuan baru yang dapat menyebabkan perubahan sikap. Mengingat peran matematika yang demikian penting maka pada setiap jenjang pendidikan formal, siswa dituntut untuk dapat mempelajari dan menguasai matematika secara baik dan benar.Pembelajaran matematika khususnya di sekolah dasar merupakan peletakan konsep dasar untuk menuju ketingkat selanjutnya. Olehnya itu, siswa diharapkan mampu dan berpartisipasi aktif dalam kegiatan pembelajaran sehingga dapat menciptakan suasana kerja sama dalam menyelesaikan permasalahan dalam matematika.

Berdasarkan hasil wawancara dengan guru kelas III SD Negeri 2 Barangka (9 Oktober 2015) dalam matapelajaran matematika yang akan diajarkan dalam semester adalah topic bangun datar dengan sub topic persegi dan persegi panjang. Kemudian juga guru mengemukakan bahwa model pembelajaran discovery learning belum terbiasa diterapkan di kelas III karena kedua hal yaitu siswa-siswa sulit menghitung keliling dan luas bangun datar ( dari Sitti hardiana S.pd). Hal ini terlihat dari nilai rata-rata hasil ulangan harian siswa tahun ajaran 2014/2015 hanya mencapai 52,8 dan hanya $40 \%$ siswa yang memperoleh nilai diatas 70 .

Terkait dengan hal tersebut, peneliti melakukan refleksi terhadap kemampuan peneliti dalam hal mengajar atau melakukan pembelajaran.Peneliti menyadari bahwa sebagai seorang calon guru yang belum memiliki pengalaman dalam mengajar tentu masih banyak kekurangan yang dimiliki dibandingkan dengan guru kelas yang sudah berpengalaman. Oleh karena itu, untuk mempersiapkan diri menjadi seorang guru, peneliti bermaksud memperbaiki kinerja dalam rangka membantu guru kelas III SD Negeri 2 Barangka meningkatkan hasil belajar siswa pada materi persegi dan persegi panjang melalui pelaksanaan PTK dengan judul "Meningkatkan Hasil Belajar Matematika Siswa Pada Materi Persegi dan Persegi Panjang Melalui Penerapan Metode Discovery Learning Di Kelas III SD Negeri 2 Barangka".

Alternatif pilihan tersebut dipilih atas dasar pendapat beberapa para ahli dengan pertimbangan bahwa pembelejaran pada siswa tingkat SD seharusnya disesuaikan dengan tingkat pemahamannya.Menurut Bruner dalam Markaban (2006:3) Tingkat pemahaman matematika seorang siswa lebih dipengaruhi oleh pengalaman siswa itu sendiri. Sedangkan pembelajaran matematika merupakan usaha membantu siswa mengkontruksi pengetahuan melalui proses.

Untuk menyikapi hasil diskusi dengan guru tersebut dalam rangka untuk meningkatkan hasil belajar matematika siswa pada materi persegi dan persegi panjang tersebut dituangkan dalam sebuah penelitian tindakan kelas dengan judul "Meningkatkan Hasil Belajar Matematika Siswa Pada Materi Persegi dan Persegi Panjang Melalui Penerapan Metode Discovery Learning di Kelas III SD Negeri 2 Barangka”.

Berdasarkan latar belakang yang telah dikemukakan, maka rumusan masalah dalam penelitian ini adalah apakah hasil belajar matematika siswa pada materi persegi dan persegi panjang di Kelas III SD Negeri 2 Barangka dapat ditingkatkan melalui penerapan metode Discovery Learning?

Penelitian ini bertujuan untuk meningkatkan hasil belajar matematika siswa pada materi persegi dan persegi panjang melalui penerapan metode discovery learning di kelas III SD Negeri 2 Barangka.

\section{Metode Penelitian}

Jenis penelitian yang digunakan dalam penelitian ini adalah penelitian tindakan kelas. adalah penelitian yang dilakukan oleh guru didalam kelasnya sendiri melalui refleksi diri dengan tujuan untuk memperbaiki kelemahan 
siswa yang ditemukan pada saat proses belajar mengajar.Dalam penelitian ini upaya perbaikan yang dilakukan adalah fokus mengajar dengan memperbaiki pemahaman siswa pada materi persegi dan persegi panjang.

Penelitian ini akan dilaksanakan di SD Negeri 2 Barangka Kabupaten Muna Barat pada semester genap tahun ajaran 2015/2016, dan yang menjadi subyek dalam penelitian ini adalah siswa Kelas III. Jadwal kegiatan penelitian yang dilakukan akan disesuaikan dengan jadwal roster yang ada di sekolah SD Negeri 2 Barangka.

Sumber data adalah siswa dan guru. Data dalam penelitian terdiri atas dua macam, yaitu data kuantitatif dan data kualitatif. Data kuantitatif diambil dengan menggunakan tes hasil belajar, sedangkan data kualitatif diambil dengan menggunakan lembar observasi dan jurnal refleksi diri.

Untuk data kuantitatif diperoleh dengan menggunakan tes hasil belajar yang dilakukan pada akhir pelaksanaan tindakan setiap siklus dengan menggunakan:

1. Untuk menentukan presentase nilai ratarata hasil belajar siswa dengan rumus:

$$
\begin{aligned}
& X=\frac{\sum X i}{N} \times 100 \% \\
& \text { Dengan : } \\
& X \quad=\text { Nilai rata-rata } \\
& \sum X i \quad=\text { Jumlah nilai yang diperoleh } \\
& \text { setiap siswa } \\
& N \quad=\text { Banyaknya Siswa yang dites }
\end{aligned}
$$

2. Menentukan presentase ketuntasan hasil belajar, dengan menggunakan rumus:

$$
\begin{aligned}
& \text { TB }=\frac{\sum T B}{N} \times 100 \% \\
& \text { Keterangan : } \\
& T B=\text { Ketuntasan belajar } \\
& \sum T B=\text { Jumlah siswa yang tuntas } \\
& \text { belajar } \\
& N=\text { Jumlah siswa secara } \\
& \text { keseluruhan }
\end{aligned}
$$

3. Untuk data kualitatif diperoleh dengan menggunakan lembar observasi dan jurnal refleksi. Untuk menentukan presentase keterlaksanaan kegiatan pembelajaran dilakukan baik guru maupun siswa menggunakan rumus:

$\frac{\text { banyaknya kegiatan yang terlaksana }}{\text { banyaknya seluruh kegiatan }} \times 100 \%$

Karso, dkk. 2011: 7.50
Indikator keberhasilan dalam penelitian ini ada dua macam, yaitu indikator tentang keterlaksanaan skenario pembelajaran dan indikator pemahaman konsep matematika siswa dalam penelitian ini.

1. Skenario pembelajaran dikatakan terlaksana dengan baik apabila minimal 90\% skenario pembelajaran terlaksana dengan sempurna.

2. Siswa-siswa yang menjadi subjek dalam penelitian ini dikatakan memahami konsep matematika yang diajarkan apabila minimal $80 \%$ siswa telah memperoleh nilai minimal 70 .

Trianto, 2013: 241

\section{Hasil Penelitian dan Pembahasan}

Hasil observasi kegiatan mengajar guru pada siklus I pertemuan pertama menunjukkan bahwa skor perolehan guru adalah 67 sedangkan skor maksimum 85. Persentase keberhasilan aktivitas mengajar guru diperoleh dari perbandingan antara skor perolehan guru dan skor maksimum dikalikan seratus persen, maka persentase keberhasilan aktivitas mengajar guru pertemuan pertama adalah $78,82 \%$ Pada pertemuan kedua siklus I menunjukkan bahwa skor perolehan guru adalah 75 sedangkan skor maksimum 85 . Maka persentase keberhasilan aktivitas mengajar guru pertemuan kedua adalah $88,23 \%$.

Sedangkan hasil observasi aktivitas belajar siswa pada siklus I pertemuan pertama menunjukkan bahwa skor yang diperoleh adalah 40 sedangkan skor maksimum adalah 65. Persentase keberhasilan aktivitas belajar siswa diperoleh dari perbandingan antara skor perolehan dari aktivitas belajar siswa dan skor maksimum dikalikan seratus persen, maka persentase keberhasilan aktivitas belajar siswa pertemuan pertama adalah 61,54\%. Pada pertemuan kedua siklus I menunjukkan skor yang diperoleh dari aktivitas belajar siswa adalah 47sedangkan skor maksimum 65. Maka persentase keberhasilan aktivitas belajarsiswa pada pertemuan kedua adalah $72,31 \%$.

Berdasarkan tes yang dilakukan menunjukan bahwa hasil belajar .matematika siswa setelah menerapkan metode discovery learning khususnya pada materi keliling persegi dan persegi panjang, hasil tes 
menunjukan bahwa hanya beberapa siswa yang mencapai nilai $\geq 70$. Dari 15 siswa kelas III yang memperoleh nilai $\geq 70$ sebanyak 10 siswa atau dengan persentase 66,66\% siswa yang mencapai KKM, sedangkan yang memperoleh nilai $<70$ sebanyak 5 siswa atau dengan persentase $33,34 \%$. dengan nilai rata-rata 33,33 .

Hasil analisis ketuntasan belajar siswa pada penelitian hasil belajar secara klasikal dapat dilihat pada tabel berikut ini.

\section{Tabel 1. Analisis Ketuntasan Hasil Belajar Siswa Pada Siklus I}

Berdasarkan hasil observasi pada siklus I, guru dan siswa telah melakukan sebagian kegiatan pembelajaran dengan baik.Namun demikian, masih terdapat kekurangan-kekurangan yang perlu diperbaiki antara lain, pada pertemuan pertama guru belum mampu mengorganisasikan waktu dengan baik. Guru juga sudah terlalu jauh dalam memberikan bimbingan kepada siswa atau kelompok yang mengalami kesulitan dalam menyelesaikan keliling persegi dan persegi panjang sehingga menyebabkan kelompok lain masih terabaikan.

Berdasarkan hasil tes belajar siswa pada siklus I, siswa yang memperoleh nilai $\geq$ 70 sebanyak 10 orang siswa atau sebesar 66,66 $\%$ dengan nilai rata-rata 71,00 . Secara klasikal mencapai persentase ketuntasan yaitu $66,66 \%$ belum mencapai target yaitu $80 \%$. hasil belajar matematika siswa pada siklus I yang belum memenuhi indikator keberhasilan dalam penelitian ini, maka penelitian ini dilanjutkan pada tindakan siklus II.

Hasil observasi kegiatan mengajar guru pada siklus II pertemuan pertama menunjukkan bahwa skor perolehan guru adalah 70 sedangkan skor maksimum 85 . Persentase keberhasilan aktivitas mengajar guru diperoleh dari perbandingan antara skor perolehan guru dan skor maksimum dikalikan seratus persen, maka persentase keberhasilan aktivitas mengajar guru pertemuan pertama adalah $91,76 \%$. Pada pertemuan kedua siklus II menunjukkan bahwa skor perolehan guru adalah 81 sedangkan skor maksimum 85 . Maka persentase keberhasilan aktivitas mengajar guru pertemuan kedua adalah $95,29 \%$.
Sedangkan hasil observasi aktivitas belajar siswa pada siklus II pertemuan pertama menunjukkan bahwa skor yang diperoleh adalah 51sedangkan skor maksimum adalah 65. Persentase keberhasilan aktivitas belajar siswa diperoleh dari perbandingan antara skor perolehan dari aktivitas belajar siswa dan skor maksimum dikalikan seratus persen, maka persentase keberhasilan aktivitas belajar siswa pertemuan pertama adalah $78,46 \%$. Pada pertemuan kedua siklus II menunjukkan skor yang diperoleh dari aktivitas belajar siswa adalah 61 sedangkan skor maksimum 65 . Maka persentase keberhasilan aktivitas belajar siswa pada pertemuan kedua adalah 93,85\%.

\begin{tabular}{ccccc}
\hline No & Ketuntasan & Skor & $\begin{array}{c}\text { Jumlah } \\
\text { siswa }\end{array}$ & $\begin{array}{c}\text { Persenta } \\
\text { se (\%) }\end{array}$ \\
\hline 1 & Tuntas & $70-100$ & 10 & $66,66 \%$ \\
2 & Belum & $0-69$ & 5 & $33,34 \%$ \\
& Tuntas & & 15 & $100 \%$ \\
\hline & Total & & 15
\end{tabular}

Berdasarkan hasil tes yang pada pelaksanaan pembelajaran yang dilakukan oleh guru sudah mencapai indikator dalam penelitian yaitu $80 \%$. Hasil belajar matematika secara klasikal yang memperoleh nilai $\geq 70$ sebanyak 13 siswa atau dengan persentase $86,66 \%$ siswa mencapai KKM, sedangkan yang memperoleh nilai < 65 sebanyak 2 siswa atau dengan persentase $13,34 \%$, dengan ratarata 81,00 .

Hasil analisis ketuntasan belajar siswa pada penelitian hasil belajar secara klasikal dapat dilihat pada tabel berikut ini:

Tabel 2. Analisis Ketuntasan Hasil Belajar Siswa Pada Siklus II

\begin{tabular}{|c|c|c|c|c|}
\hline No & $\begin{array}{c}\text { Ketunta } \\
\text { san }\end{array}$ & Skor & $\begin{array}{c}\text { Jumlah } \\
\text { siswa }\end{array}$ & $\begin{array}{c}\text { Persentase } \\
(\%)\end{array}$ \\
\hline 1 & Tuntas & $70-100$ & 13 & $86,66 \%$ \\
\hline 2 & $\begin{array}{l}\text { Belum } \\
\text { Tuntas }\end{array}$ & $0-69$ & 2 & $13,34 \%$ \\
\hline Tota & & & 15 & $100 \%$ \\
\hline
\end{tabular}

Ketercapaian aktivitas guru dan siswa dalam proses pembelajaran pada siklus II yaitu pertemuan pertama aktivitas guru sebesar $91,76 \%$ dan pertemuan kedua meningkat menjadi 95,29\%. Sedangkan aktivitas belajar siswa siklus II yaitu pertemuan pertama sebesar $78,46 \%$ dan pertemuan kedua meningkat menjadi $93,85 \%$. 
Berdasarkan hasil tes belajar siswa pada siklus II, siswa yang memperoleh nilai $\geq$ 70 sebanyak 13 orang siswa atau sebesar 86,66 $\%$ dengan nilai rata-rata 81,00. Secara klasikal mencapai persentase ketuntasan yaitu $86,00 \%$ telah mencapai target yaitu $80 \%$. Ini pulamengalami peningkatan sebesar 10,00\% dari hasil tes yang diperoleh pada siklus I.

Dari hasil tes belajar siswa yang diperoleh pada siklus II, dapat dikatakan bahwa penerapan metode Discovery Learning memberikan dampak yang positif terhadap hasil belajar siswa. Hal ini sejalan dengan pengertian pmbelajaran Discovery Learning merupakan proses belajar di mana guru harus menciptakan situasi belajar yang problematis, menstimulus siswa dengan pertanyaanpertanyaan, mendorong siswa mencari jawaban sendiri. Bentuk lain dari belajar penemuan adalah guru menyajikan contoh-contoh dan siswa bekerja dengan contoh tersebut sampai dapat menemukan sendiri hubungan antarkonsep.

Karena indikator keberhasilan dalam penelitian ini telah tercapai, dalam hal ini minimal $80 \%$ siswa telah mencapai nilai $\geq 70$, maka penelitian ini dihentikan sampai pada siklus II. Ini berarti bahwa, hipotesis tindakan telah terjawab yaitu dengan melalui penerapan metode Discovery Learninghasil belajar siswa pada materi persegi dan persegi panjang dapat ditingkatkan.

\section{Simpulan}

Berdasarkan hasil penelitian dan pembahasan pada setiap siklus dari penelitian ini, maka dapat disimpulkan bahwa penerapan metode Discovery Learning dapat meningkatkan hasil belajar matematika siswa pada materi persegi dan persegi panjang di kelas III SD Negeri 2 Barangka. Peningkatan terlihat dari hasil tes belajar siswa, ketuntasan klasikal siswa pada siklus I mencapai $66,66 \%$ dengan nilai rata-rata 71,00 sedangkan pada siklus II ketuntasan klasikal siswa meningkat menjadi $86,66 \%$ dengan nilai rata-rata 81,00 .

\section{Daftar Pustaka}

Abimayu, Soli. dkk. 2008. Strategi Pembelajaran. Jakarta: Direktorat Jenderal Pendidikan Tinggi Departemen pendidikan Nasional
Aisyah, Nyimas, dkk. 2008. Pengembangan pembelajaran Matematika SD. Jakarta: Departemen Pendidikan Nasional

Daryanto. 2013. Inovasi Pembelajaran Efektif. Bandung: Yrama Widya

Karso, dkk. 2011. Pendidikan Matematika I. Jakarta: Universitas Terbuka

Susanto, Ahmad. 2015. Tori belajar dan pembelajaran di sekolah dasar. Edisi ketiga. Jakarta: Prenada Media Grup

Wardhani, I.G.A.K. \& Kuswaya Wihardit. 2009. Penelitian tindakan kelas. Jakarta: Universitas Jakarta 